\title{
Candida dubliniensis sp. nov.: phenotypic and molecular characterization of a novel species associated with oral candidosis in HIV-infected individuals
}

\author{
Derek J. Sullivan, ${ }^{1,2}$ Thea J. Westerneng, ${ }^{3}$ Ken A. Haynes, ${ }^{3}$ \\ Désirée E. Bennett ${ }^{1,2}$ and David C. Coleman ${ }^{1,2}$ \\ Author for correspondence: David C. Coleman. Tel: +3531 6081814. Fax: +35316799294. \\ e-mail: dcoleman@mail.tcd.ie
}

1 University of Dublin, School of Dental Science, Department of Oral Medicine and Pathology, Trinity College, Dublin 2, Republic of Ireland

2 University of Dublin, The Moyne Institute, Department of Microbiology, Trinity College, Dublin 2, Republic of Ireland

3 Charing Cross and Westminster Medical School, Department of Medical Microbiology, London W6 8RF, UK

\begin{abstract}
Atypical oral Candida isolates were recovered from $60 \mathrm{HIV}$-infected and three HIV-negative individuals. These organisms were germ-tube-positive and produced abundant chlamydospores which were frequently arranged in triplets or in contiguous pairs. They belonged to $C$. albicans serotype $A$ and had atypical carbohydrate assimilation profiles. Fingerprinting the genomic DNA of a selection of these organisms with the $C$. albicans-specific probe 27A and five separate oligonucleotides, homologous to eukaryotic microsatellite repeat sequences, demonstrated that they had a very distinct genomic organization compared to $C$. albicans and C. stellatoidea. This was further established by random amplified polymorphic DNA (RAPD) and karyotype analysis. Comparison of $\mathbf{5 0 0}$ bp of the V3 variable region of the large ribosomal subunit genes from nine atypical isolates and the corresponding sequences determined from C. albicans, C. stellatoidea, C. tropicalis, C. parapsilosis, C. glabrata, C. kefyr and C. krusei showed that the atypical organisms formed a homogeneous cluster ( $100 \%$ similarity) that was significantly different from the other Candida species analysed, but was most closely related to C. albicans and C. stellatoidea. These genetic data combined with the phenotypic characteristics of these atypical organisms strongly suggest that they constitute a novel species within the genus Candida for which the name Candida dubliniensis is proposed.
\end{abstract}

Keywords: Candida dubliniensis sp. nov., tRNA gene sequences, phylogenetic position, oral candidosis, AIDS

\section{INTRODUCTION}

Fungal taxonomy is problematic because of reliance on phenotypic and morphological characteristics for classification. Increasingly the speciation of fungi with many

Abbreviations: RAPD, random amplified polymorphic DNA; RAT agar, rice-agar-Tween agar.

The EMBL and GenBank accession numbers for the nucleotide sequences reported in this paper are X83716 (Candida stellatoidea ATCC 20408), X83717 (Candida albicans 132A), X83718 (Candida dubliniensis NCPF 3949), 248340 (Aspergillus fumigatus NCPF 2109), Z48341 (Candida glabrata 11088A), Z48342 (Candida krusei 105-1), Z48343 (Candida parapsilosis 44), Z48344 (Candida kefyr NCPF 3234) and Z48346 (Candida tropicalis NCPF 3111).

The British National Collection of Pathogenic Fungi accession number for Candida dubliniensis sp. nov. described in this paper is NCPF 3949. morphological and phenotypic characteristics in common is likely to depend on genetic characterization (Check, 1994). In this regard, molecular analysis has yielded some surprising findings; e.g. until recently Pneumocystis carinii was considered to be a protozoan but rRNA gene sequence analysis has revealed that it is more closely related to fungi (Edman et al., 1988; Wakefield et al., 1992). Species of the genus Candida have been classically identified on the basis of biochemical reactions and morphological features because of the lack of sexual reproduction. However, phenotypic parameters such as substrate assimilation, cell wall composition and production of extracellular proteolytic enzymes can vary greatly within some species such as Candida albicans (Williamson et al., 1986; Ghannoum et al., 1990; Martinez et al., 1990; Allen \& Beck, 1983; Odds, 1988a), making 
the concept of species unclear to some extent. This has led to much confusion in the classification of Candida species. The taxonomic relationship between $C$. albicans and the closely related $C$. stellatoidea is illustrative of the present position, with many researchers now accepting the latter as a variant or synonym of C. albicans (Odds, 1988b; Barnett et al., 1990 ). Similarly, C. pseudotropicalis is now considered to be a synonym of $C$. kefyr (Odds, 1988b). However, there is an ongoing debate as to whether the two genera Candida and Torulopsis should be merged (Odds, 1998b). It is therefore not surprising that several recent studies described isolates of Candida whose properties did not conform precisely with conventional species definitions (Akisada et al., 1983; Mahrous et al., 1990; Schmid et al., 1992; Sullivan et al., 1993; McCullough et al., 1995).

The present study was originally prompted by the recovery of unusual isolates of oral Candida from 20 separate HIV-infected and AIDS patients with a history of recurrent oral candidosis attending the Dublin Dental Hospital between March 1991 and September 1992. These isolates produced chlamydospores, but were not readily identifiable as $C$. albicans or $C$. stellatoidea on the basis of carbohydrate assimilation profiles. Furthermore, restriction-endonuclease-digested genomic DNA from these isolates yielded weak hybridization profiles consisting of a small number of bands when probed with the cloned C. albicans-specific mid-repeat sequence probe $27 \mathrm{~A}$, compared to the large number of strongly hybridizing bands obtained with DNA from C. albicans isolates. DNA from these atypical isolates also yielded distinctive fingerprint patterns when probed with oligonucleotides (Coleman et al., 1993; Sullivan et al., 1993). Since our original study reporting these atypical Candida isolates, we have identified a significant number of similar isolates from additional HIV-infected and AIDS patients attending the Dublin Dental Hospital.

Here we report a detailed phenotypic and genotypic analysis of representative atypical Candida isolates recovered in Dublin and similar isolates recovered from AIDS patients in Australia, which establishes them as a unique group within the genus Candida for which we propose the name Candida dubliniensis.

\section{METHODS}

Yeast strains and clinical isolates. Sixty-four atypical oral Candida isolates which were recovered between August 1988 and September 1994 were studied: 55 were isolated from separate HIV-infected patients attending the Dublin Dental Hospital, and of these, 47 were intravenous drug users, six were homosexuals and two were haemophiliacs. Thirty-seven of these patients had full blown AIDS at the time of isolate recovery. Two atypical oral Candida isolates were recovered from HIV-negative intravenous drug users attending the Dublin Dental Hospital and one isolate was recovered from a HIV-negative healthy Irish subject. The remaining six isolates were recovered from five separate AIDS patients attending the Fairfield Hospital, Melbourne, Australia between November 1989 and April 1992. Two isolates were recovered from one of these patients at separate clinical evaluations. Other yeast strains and representative atypical isolates used for detailed analysis in the study are listed in Table 1 . In a previous study, we found that C. stellatoidea NCPF 3108 was phenotypically and genotypically indistinguishable from the atypical Candida isolates (Sullivan $e t$ al., 1993), and therefore it has been included with them throughout the text. A group of 20 non-oral clinical isolates of C. albicans were also included in the study for comparison in some experiments. These were epidemiologically unrelated isolates recovered from separate HIV-negative individuals. Seven of these isolates were recovered from blood cultures, eight from vaginal specimens, three from faecal specimens and two from urine samples.

The yeasts were grown routinely on Potato Dextrose Agar (PDA, Oxoid) at $\mathrm{pH} 5.6$ for $48 \mathrm{~h}$ at $37^{\circ} \mathrm{C}$. For liquid culture, isolates and strains were routinely grown in Yeast Peptone Dextrose Broth [YPD; $\left(1^{-1}\right) 10 \mathrm{~g}$ yeast extract (Oxoid), $20 \mathrm{~g}$ peptone (Difco), $20 \mathrm{~g}$ glucose, $\mathrm{pH} 5.5]$ at $37^{\circ} \mathrm{C}$ in an orbital incubator (Gallenkamp) set at 180 r.p.m. Germ tube tests were performed by inoculating $2.0 \mathrm{ml}$ fresh, pooled, normal human serum with a fresh colony of yeast and incubating at $37^{\circ} \mathrm{C}$ for $2 \mathrm{~h}$ in a waterbath. Chlamydospore, pseudohyphal and hyphal production were assessed on rice-agar-Tween agar (RAT agar; bioMérieux) and cornmeal agar (Oxoid), supplemented with $1 \%(\mathrm{v} / \mathrm{v})$ Tween $80($ Sigma), following inoculation with a 48h-old yeast colony. The inoculum was applied in several shallow parallel grooves in the agar, covered with a sterile coverslip and incubated for $2-3 \mathrm{~d}$ at $25-27^{\circ} \mathrm{C}$ in the dark. Germ tubes were observed under bright-field illumination using a Nikon microscope (model 71610). Inoculated RAT agar plates were examined for chlamydospore production by microscopy with bright-field illumination using a Nikon microscope. Samples from RAT and cornmeal agar plates were also examined after staining with lactophenol cotton blue stain. A drop of $1 \%$ $(\mathrm{w} / \mathrm{v})$ lactophenol cotton blue stain (Larone, 1993) was spotted directly onto an inoculated RAT agar plate, having gently prised up the glass cover slip covering the culture growth, and recovering the stained area by replacing the cover slip. Plates were examined by microscopy $30 \mathrm{~min}$ after staining. Estimates of the relative ability of atypical and reference Candida to produce chlamydospores on RAT agar were made using an arbitrary scale of $(+)$ to $(+++++)$, where $(+)$ and $(++)$ denote low-level chlamydospore production and $(+++++)$ denotes hyper-chlamydospore production. Atypical isolates were further tested for their ability to form true hyphae using $N$-acetylglucosamine-yeast nitrogen base-proline (NYP) liquid medium (Marichal et al., 1986). This medium promotes growth of $C$. albicans in the hyphal form in a humidified atmosphere of $10 \%(\mathrm{v} / \mathrm{v}) \mathrm{CO}_{2}$ at $37^{\circ} \mathrm{C}$. Following incubation for $24 \mathrm{~h}$, plates containing inoculated NYP medium were examined for hyphal formation by light microscopy.

The ability of the atypical isolates to assimilate a variety of carbohydrate-source compounds was determined using the API ID $32 \mathrm{C}$ yeast identification system (bioMérieux), according to the manufacturer's instructions. The assimilation profiles of each isolate were examined on three separate occasions using different batches of ID $32 \mathrm{C}$ kits. Nitrate assimilation was assayed according to the method described by Buckley (1989).

Chemicals, enzymes, radioisotopes and oligonucleotides. Analar-grade or molecular biology-grade chemicals were purchased from Sigma, $\mathrm{BDH}$ or Boehringer Mannheim. $\left[\gamma^{32} \mathrm{P}\right] \mathrm{dATP} \quad\left(5000 \mathrm{Ci} \mathrm{mmol}{ }^{-1} ; 185 \mathrm{TBq} \mathrm{mmol}^{-1}\right)$ and $[\alpha-$ $\left.{ }^{32} \mathrm{P}\right] \mathrm{dATP}\left(3000 \mathrm{Ci} \mathrm{mmol}^{-1} ; 110 \mathrm{TBq}^{-1}\right.$ ) were purchased from Amersham. Enzymes were purchased from the Promega Corporation or from Boehringer Mannheim and were used according to the manufacturer's instructions.

Serotyping. Candida isolates were serotyped on the basis of 
Table 1. Reference strains and clinical isolates

\begin{tabular}{|c|c|c|c|}
\hline Strain/isolate* & Source & Reference & $\begin{array}{l}\text { rRNA gene V3 } \\
\text { sequence } \\
\text { accession no. }\end{array}$ \\
\hline \multicolumn{4}{|l|}{ C. albicans } \\
\hline $132 \mathrm{~A}$ & Irish oral isolate from $\mathrm{HIV}^{+}$patient & Gallagher et al. (1992) & $\mathrm{X} 83717 \dagger$ \\
\hline 179B & Irish oral isolate from $\mathrm{HIV}^{+}$patient & Gallagher et al. (1992) & - \\
\hline CM3 & Australian oral isolate from $\mathrm{HIV}^{+}$patient & This study & - \\
\hline WO-1 & American isolate from blood culture & Slutsky et al. (1987) & L28817 \\
\hline Unnamed & Canadian vaginal isolate & Mercure et al. (1993) & $\mathrm{X} 70659$ \\
\hline \multicolumn{4}{|l|}{ C. stellatoidea } \\
\hline 11006 (type I) & American Type Culture Collection (MD, USA) & Kwon-Chung et al. (1989) & - \\
\hline 20408 (type II) & American Type Culture Collection (MD, USA) & Kwon-Chung et al. (1989) & $\mathrm{X} 83716 \ddagger$ \\
\hline \multicolumn{4}{|c|}{$\begin{array}{l}\text { Atypical Candida } \\
\text { (C. dubliniensis sp. nov.) }\end{array}$} \\
\hline $\mathrm{CD} 33$ & Irish oral isolate from $\mathrm{HIV}^{+}$patient & This study & - \\
\hline $\mathrm{CD} 34$ & Irish oral isolate from $\mathrm{HIV}^{+}$patient & This study & - \\
\hline $\mathrm{CD} 36$ & Irish oral isolate from $\mathrm{HIV}^{+}$patient & NCPF 3949 , this study & $\mathrm{X} 83718 \int$ \\
\hline $\mathrm{CD} 37$ & Irish oral isolate from $\mathrm{HIV}^{+}$patient & This study & - \\
\hline CD38 & Irish oral isolate from $\mathrm{HIV}^{+}$patient & This study & - \\
\hline $\mathrm{CD} 40$ & Irish oral isolate from $\mathrm{HIV}^{+}$patient & This study & - \\
\hline CD41 & Irish oral isolate from $\mathrm{HIV}^{-}$healthy subject & This study & - \\
\hline CM1 & Australian oral isolate from $\mathrm{HIV}^{+}$patient & This study & - \\
\hline CM2 & Australian oral isolate from $\mathrm{HIV}^{+}$patient & This study & - \\
\hline CM4 & Australian oral isolate from $\mathrm{HIV}^{+}$patient & This study & - \\
\hline CM5 & Australian oral isolate from $\mathrm{HIV}^{+}$patient & This study & - \\
\hline CM6 & Australian oral isolate from $\mathrm{HIV}^{+}$patient & This study & - \\
\hline CM7 & Australian oral isolate from $\mathrm{HIV}^{+}$patient & This study & - \\
\hline 3108 & National Collection of Pathogenic Fungi (UK) & NCPF 3108; Sullivan et al. (1993) & - \\
\hline \multicolumn{4}{|l|}{ C. tropicalis } \\
\hline 3111 & National Collection of Pathogenic Fungi (UK) & NCPF 3111 & Z48346 \\
\hline \multicolumn{4}{|l|}{ C. parapsilosis } \\
\hline 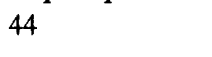 & CXWMS, London $\|$ & This study & Z48343 \\
\hline \multicolumn{4}{|l|}{ C. glabrata } \\
\hline $11088 \mathrm{~A}$ & CXWMS, London\| & This study & Z48341 \\
\hline \multicolumn{4}{|l|}{ C. kefyr } \\
\hline 3234 & National Collection of Pathogenic Fungi (UK) & NCPF 3234 & Z48344 \\
\hline \multicolumn{4}{|l|}{ C. krusei } \\
\hline $105-1$ & CXWMS, London $\|$ & This study & Z48342 \\
\hline \multicolumn{4}{|c|}{ Aspergillus fumigatus } \\
\hline 2109 & National Collection of Pathogenic Fungi (UK) & NCPF 2109 & Z48340 \\
\hline
\end{tabular}

${ }^{*}$ C. stellatoidea is currently considered a synonym of $C$. albicans (Odds, 1988b; Barnett et al., 1990) and $C$. kefyr is currently considered a synonym of $C$. pseudotropicalis (Odds, 1988b).

† The rRNA gene V3 region sequences obtained from C. albicans strains 132A (serotype B) and 179B (serotype A) were identical.

$\ddagger$ The rRNA gene V3 region sequences obtained from the C. stellatoidea type II and type I strains ATCC 20408 and ATCC 11006 , respectively, were identical.

The rRNA gene $\mathrm{V} 3$ region sequence obtained from the $C$. dubliniensis isolate $\mathrm{CD} 36$ was identical to the corresponding sequences of the C. dubliniensis isolates CD34, CD37, CD38, CD40, CM2, CM5, CM7 and NCPF 3108.

\| Clinical isolates recovered during 1993 at the Charing Cross and Westminster Medical School (CXWMS). 
Table 2. Oligonucleotide primers used in the analysis of atypical Candida isolates and reference Candida strains

\begin{tabular}{|c|c|c|c|}
\hline Oligonucleotide & Nucleotide sequence $5^{\prime}-3^{\prime}$ & Used for & Reference \\
\hline 1 & $(\text { GGAT })_{4}$ & Hybridization probe & Sullivan et al. (1993) \\
\hline 2 & $(\mathrm{GACA})_{4}$ & Hybridization probe & Sullivan et al. (1993) \\
\hline 3 & $(\mathrm{GATA})_{4}$ & Hybridization probe & Sullivan et al. (1993) \\
\hline 4 & $(G T)_{8}$ & Hybridization probe & Sullivan et al. (1993) \\
\hline 5 & $(\mathrm{GTG})_{5}$ & Hybridization probe & Sullivan et al. (1993) \\
\hline 6 & GCGATCCCCA & RAPD & A kopyanz et al. (1992) \\
\hline 7 & AGTGAATTCGCGGTGAGATGCCA & RAPD & Akopyanz et al. (1992) \\
\hline 8 & AACGCGCAAC & RAPD & Akopyanz et al. (1992) \\
\hline 9 & ATTACTGACGCTGATTGTGC & RAPD & Akopyanz et al. (1992) \\
\hline 10 & CCGCAGCCA & RAPD & Akopyanz et al. (1992) \\
\hline 11 & GCATATCAATAAGCGGAGGAAAAG & rRNA gene analysis & Fell (1993) \\
\hline 12 & GGTCCGTGTTTCAAGACG & rRNA gene analysis & Fell (1993) \\
\hline
\end{tabular}

agglutination reactions with commercially available antiserum raised against Candida antigenic factor number 6 (Iatron Laboratories). Isolates which agglutinated with the antiserum were classified as serotype $A$ and isolates which did not agglutinate were classified as serotype B (non-serotype A). C. albicans strains $179 \mathrm{~B}$ (serotype A) and 132A (serotype B) (Gallagher et al., 1992) were used in control reactions. Isolates were serotyped on at least two separate occasions with different batches of antisera.

Isolation of genomic DNA and DNA fingerprinting. Total cellular DNA from Candida isolates was prepared from spheroplasts by using a modification of the methods described by Durkacz et al. (1985) and Pearce \& Howell (1991) as described by Gallagher et al. (1992). The procedure used for EcoRI digestion of genomic DNA was as described by Coleman et al. (1986). Restriction fragments were separated by electrophoresis through $0.8 \%$ horizontal agarose gels using $0.5 \times \mathrm{TBE}$ buffer (Sambrook et al., 1989) as the electrophoresis buffer for $18 \mathrm{~h}$ at $3 \mathrm{~V} \mathrm{~cm}^{-1}$. Following electrophoresis, DNA fragments were transferred to MagnaGraph nylon membrane filters (MSI) by the method of Southern (1975). These filters were hybridized consecutively with the $C$. albicans-specific mid-repeat sequence probe 27A (Scherer \& Stevens, 1988) and five separate synthetic oligonucleotide probes (oligonucleotides 1-5, Table 2) as described by Sullivan et al. (1993). Following hybridization with each probe, filters were stripped of bound probe by incubation in a boiling solution of $0.5 \%$ SDS for $5 \mathrm{~min}$ followed by brief washing in distilled water. Experiments were repeated on at least two occasions with separate preparations of genomic DNA.

Randomly amplified polymorphic DNA (RAPD) analysis. Five additional oligonucleotide primers (oligonucleotides 6-10, Table 2) were used in RAPD experiments as described previously (Sullivan et al., 1993). Briefly, the conditions used were as follows: approximately $10 \mathrm{ng}$ of Candida total cellular DNA was added to a $0.5 \mathrm{ml}$ microfuge tube (Eppendorf) containing $20 \mathrm{pmol}$ of the oligonucleotide primer, $250 \mu \mathrm{M}$ (each) dATP, dTTP, dCTP and dGTP (Boehringer Mannheim), $3 \mathrm{mM} \mathrm{MgCl}_{2}, 2.5 \mathrm{U}$ Taq DNA polymerase and $1 \times$ Taq buffer (Promega) in a final volume of $25 \mu \mathrm{l}$. Amplification reactions were performed in a Perkin Elmer Cetus DNA thermal cycler using the following cycling conditions: 4 cycles of $94^{\circ} \mathrm{C}$ for $5 \mathrm{~min}, 36^{\circ} \mathrm{C}$ for $5 \mathrm{~min}$ and $72{ }^{\circ} \mathrm{C}$ for $5 \mathrm{~min}$, followed by 30 cycles of $94^{\circ} \mathrm{C}$ for $1 \mathrm{~min}, 36^{\circ} \mathrm{C}$ for $1 \mathrm{~min}$ and $72{ }^{\circ} \mathrm{C}$ for $2 \mathrm{~min}$.
This was followed by a final incubation at $72{ }^{\circ} \mathrm{C}$ for $10 \mathrm{~min}$. Reaction products were separated in $2.0 \%(\mathrm{w} / \mathrm{v})$ agarose gels containing $0.5 \mu \mathrm{g}$ ethidium bromide $\mathrm{ml}^{-1}$ and viewed on a UV transilluminator (UVP). Experiments were repeated on at least two occasions with separate preparations of target genomic DNA.

Pulsed-field gel electrophoresis (PFGE). Yeast chromosomes were prepared in agarose plugs as described by Vazquez et al. (1991) and separated in $1.4 \%(\mathrm{w} / \mathrm{v})$ agarose gels using the CHEF-Mapper PFGE system (Bio-Rad). The electrophoresis buffer used was $0.5 \times \mathrm{TBE}$ and was maintained at $14^{\circ} \mathrm{C}$ using buffer recycling through a Bio-Rad minichiller (model 1000). Gels were run for $72 \mathrm{~h}$ with an initial switch time of $40 \mathrm{~s}$ and a final switch time of $600 \mathrm{~s}$ with a ramping factor of $-2 \cdot 379$. Following electrophoresis, gels were stained with $0.5 \mu \mathrm{g}$ ethidium bromide $\mathrm{ml}^{-1}$ for $20 \mathrm{~min}$, destained for between 20 and $90 \mathrm{~min}$ in distilled water and viewed on a UV transilluminator.

rRNA gene nucleotide sequence analysis. A PCR product of approximately $600 \mathrm{bp}$ was amplified from yeast isolates using universal primers (primers 11 and 12, Table 2) specific for the V3 variable region of the large ribosomal subunit gene as described by Fell (1993). Reactions were performed in a final reaction mixture $(50 \mu \mathrm{l})$ containing $10 \mathrm{pmol}$ each of primer; $200 \mu \mathrm{M}$ each of dATP, dTTP, dGTP and dCTP (Promega); $2.5 \mathrm{mM} \mathrm{MgCl}_{2} ; 2.5 \mathrm{U} \mathrm{Taq}$ DNA polymerase (Promega) $; 1 \times$ Taq reaction buffer (Promega) and approximately $10 \mathrm{ng}$ Candida total cellular DNA. Amplification reactions were performed in a Perkin Elmer Cetus DNA thermal cycler (model 9600) using the following cycling parameters: $94^{\circ} \mathrm{C}$ for $2 \mathrm{~min}$ followed by 30 cycles of $94^{\circ} \mathrm{C}$ for $30 \mathrm{~s}, 66^{\circ} \mathrm{C}$ for $90 \mathrm{~s}$ and $72{ }^{\circ} \mathrm{C}$ for $15 \mathrm{~s}$ with a final extension at $72{ }^{\circ} \mathrm{C}$ for $4 \mathrm{~min}$. Amplified PCR products were purified by adding $300 \mu \mathrm{l}$ filtered sterile water and centrifuging at 3000 r.p.m. through a Microcon 100 tube (Amicon) for 15 min using a Microcentaur microfuge (MSE). The DNA was washed twice with $400 \mu$ l sterile water by centrifugation as above and eluted by incubation with $50 \mu \mathrm{l} \mathrm{TE}$ buffer (10 mM Tris/HCl, pH 7·5, $1 \mathrm{mM}$ EDTA) for $15 \mathrm{~min}$ at room temperature and centrifugation as described above for $30 \mathrm{~s}$. Aliquots $(2 \mu \mathrm{l})$ of each sample were then electrophoresed on a $1 \%(\mathrm{w} / \mathrm{v})$ agarose gel and their DNA concentrations estimated. The amplified DNA products were then sequenced in both directions using the PRISM Ready Reaction DyeDeoxy Terminator Cycle Sequencing Kit (Applied Biosystems) ac- 
cording to the manufacturer's instructions using PCR primers 11 and 12 as sequencing primers (Table 2). Completed sequencing reactions were electrophoresed on a ABI $373 \mathrm{~A}$ Sequencer as described by the manufacturer and the data analysed using the computer programme SEQED (Applied Biosystems). Multiple sequence alignments were performed on a $500 \mathrm{bp}$ internal region of each amplified product using the CLUSTAL w sequence analysis program (Thompson et al., 1994) and the data used to construct a genetic distance matrix incorporating corrections for multiple base changes according to the method of Jukes \& Cantor (1969). A phylogenetic tree was generated from the data in this matrix using the neighbourjoining method of Saitou \& Nei (1987) and was further tested using bootstrap analysis (Felsenstein, 1985).

\section{RESULTS}

\section{Phenotypic characterization}

Although all 64 atypical oral Candida isolates and NCPF 3108 grew well at 30 and $37^{\circ} \mathrm{C}$, neither they, nor the type I C. stellatoidea reference strain ATCC 11006 , were able to grow at $42{ }^{\circ} \mathrm{C}$ on PDA or in YPD. This was contrary to the results obtained with the three oral $C$. albicans strains $132 \mathrm{~A}, 179 \mathrm{~B}$ and CM3, the 20 non-oral C. albicans control clinical isolates and the type II C. stellatoidea strain ATCC 20408 , all of which grew at this temperature.

All of the atypical isolates exhibited one of three very similar carbohydrate-source assimilation profiles with the API ID 32C yeast identification system (Table 3), none of which corresponded exactly with any known Candida species profile in the API APILAB database. All of the isolates showed positive assimilation reactions for the carbohydrate substrates galactose, sucrose, maltose, $\mathrm{N}$ acetylglucosamine, sorbitol, mannitol, 2-keto-gluconate, glucose and glucosamine, but were unable to utilize 18 other carbon-source and nitrogen-source substrates tested (Table 3). Twenty-six of the isolates did not assimilate trehalose, and in addition six of these did not assimilate palatinose (Table 3). All of the atypical isolates were able to grow in the presence of cycloheximide and none of them could hydrolyse aesculin. In addition, none of the atypical isolates, nor the reference Candida strains tested could assimilate nitrate.

All 65 atypical isolates were found to be germ-tubepositive, to produce pseudohyphae and thick-walled chlamydospores on RAT and cornmeal agar, and to be of C. albicans serotype A. However, the pattern of chlamydospore production by the atypical isolates was quite distinct compared to reference $C$. albicans and $C$. stellatoidea strains. The former produced chlamydospores in copious amounts $(+++++$; see Methods). Characteristically, these were attached to short pseudohyphae with abundant lateral branching and frequently occurred terminally in triplets or in contiguous pairs (Fig. 1b, c). Staining with $1 \%(\mathrm{w} / \mathrm{v})$ lactophenol cotton blue preferentially stained the chlamydospores intensely, allowing them to be distinguished from suspensor cells, pseudomycelium and blastospores, which stained poorly or not at all (Fig. 1d). This phenomenon was observed on both RAT and cornmeal agar. In contrast, the oral $C$. albicans strains
$132 \mathrm{~A}$ (serotype $\mathrm{B}$ ) and $179 \mathrm{~B}$ (serotype $\mathrm{A}$ ), and the $C$. stellatoidea strains A TCC 11006 (type I) and ATCC 20408 (type II) produced very much smaller numbers of chlamydospores $(+$ to ++$)$, which occurred singly and were attached terminally to pseudohyphae (Fig. 1a), although in a small number of preparations contiguous pairs of chlamydospores were observed. Similar low-level production of chlamydospores $(+$ to ++ ) was observed for the 20 non-oral $C$. albicans control isolates and for 418 separate oral isolates of $C$. albicans from Irish HIVinfected $(n=310)$ and age- and gender-matched healthy control subjects $(n=108)$ which were recovered during the same period as the atypical isolates. The predominant mycelial form produced by the atypical isolates on RAT and cornmeal agar was pseudohyphae, although a few true hyphae were observed following prolonged incubation ( $72 \mathrm{~h}$ ). All of eight $C$. albicans reference isolates tested were also found to produce true hyphae in NYP medium at $37{ }^{\circ} \mathrm{C}$ in a humidified atmosphere of $10 \%$ (v/v) $\mathrm{CO}_{2}$.

\section{Genomic DNA fingerprinting analysis}

Thirty-four of the atypical isolates, including 28 Irish and the 6 Australian isolates, were chosen for DNA fingerprinting analysis. Genomic DNA was digested with the restriction enzyme EcoRI and following separation of the fragments, direct visual analysis of the gross patterns obtained allowed the atypical isolates to be readily differentiated from the oral $C$. albicans strains $132 \mathrm{~A}$ and $179 \mathrm{~B}$, from the 20 non-oral C. albicans control isolates and from the $C$. stellatoidea strains ATCC 11006 (type I) and ATCC 20408 (type II) (data not shown). However, these differences were more pronounced when the digested DNA preparations were transferred to nylon membrane filters and hybridized with the ${ }^{32} \mathrm{P}$-labelled $C$. albicansspecific, mid-repeat sequence DNA probe $27 \mathrm{~A}$. The probe hybridized efficiently to the EcoRI-digested DNA isolated from the $C$. albicans (oral and non-oral) and from the $C$. stellatoidea reference strains, yielding 10-15 bands ranging in size between approximately $500 \mathrm{bp}$ and $20 \mathrm{~kb}$ (Fig. 2a, lanes 1-4). The same probe, however, bound poorly to DNA purified from the atypical isolates, yielding hybridization profiles containing only 4-7 bands, most of which were weak and ranging in size between 5 and $20 \mathrm{~kb}$ (Fig. 2a, lanes 5-11). Identical results were obtained in repeat experiments with separate preparations of genomic DNA.

Genomic DNA from 17 of the atypical isolates (11 Irish and 6 Australian) and the reference C. albicans (oral) and C. stellatoidea strains described above was examined in more detail. DNA preparations were digested with the restriction endonuclease HinfI, which cleaves DNA more frequently than EcoRI, and the fragments separated by agarose gel electrophoresis. The atypical isolates were characterized by the presence of a very high molecular mass Hinf I fragment (approximately $15 \mathrm{~kb}$ ), which was not detected in the HinfI digests of DNA from the $C$. albicans strains $132 \mathrm{~A}$ and $\mathrm{CM} 3$ or from the $C$. stellatoidea strains ATCC 11006 (type I) and ATCC 20408 (type II) 
Table 3. Substrate assimilation by atypical Candida isolates and reference strains of $C$. albicans and $C$. stellatoidea

Substrate utilization was determined using the API ID $32 \mathrm{C}$ yeast identification system. Each isolate was tested on three separate occasions with three different batches of ID $32 \mathrm{C}$ kits.

\begin{tabular}{|c|c|c|c|c|c|c|c|}
\hline \multirow[t]{2}{*}{ Substrate } & \multicolumn{3}{|c|}{ Atypical isolates* } & \multicolumn{2}{|c|}{ C. albicans* } & \multicolumn{2}{|c|}{ C. stellatoidea* } \\
\hline & $\begin{array}{c}\text { A } \\
n=33\end{array}$ & $\begin{array}{c}\text { B } \\
26\end{array}$ & $\begin{array}{l}C \\
6\end{array}$ & $132 \mathrm{~A}$ & 179B & $\begin{array}{c}\text { Type I } \\
\text { ATCC } 11006\end{array}$ & $\begin{array}{c}\text { Type II } \\
\text { ATCC } 20408\end{array}$ \\
\hline \multicolumn{8}{|l|}{ Pentoses } \\
\hline L-Arabinose & - & - & - & - & - & - & - \\
\hline D-Xylose & - & - & - & - & + & + & + \\
\hline Ribose & - & - & - & - & - & - & - \\
\hline \multicolumn{8}{|l|}{ Hexoses } \\
\hline$\alpha$-Methyl-D-glucoside & - & - & - & + & + & - & - \\
\hline Galactose & + & + & + & + & + & + & + \\
\hline Glucose & + & + & + & + & + & + & + \\
\hline Sorbose & - & - & - & - & - & - & - \\
\hline Rhamnose & - & - & - & - & - & - & - \\
\hline \multicolumn{8}{|l|}{ Disaccharides } \\
\hline Cellobiose & - & - & - & - & - & - & - \\
\hline Maltose & + & + & + & + & + & + & + \\
\hline Lactose & - & - & - & - & - & - & - \\
\hline Melibiose & - & - & - & - & - & - & - \\
\hline Sucrose & + & + & + & + & + & - & - \\
\hline Trehalose & + & - & - & + & + & - & + \\
\hline Palatinose & + & + & - & + & + & - & - \\
\hline \multicolumn{8}{|l|}{ Trisaccharides } \\
\hline Melezitose & - & - & - & - & - & - & - \\
\hline Rafinose & - & - & - & - & - & - & - \\
\hline \multicolumn{8}{|l|}{ Alcohols } \\
\hline Glycerol & - & - & - & - & - & - & - \\
\hline Erythritol & - & - & - & - & - & - & - \\
\hline Mannitol & + & + & + & + & + & + & + \\
\hline Inositol & - & - & - & - & - & - & - \\
\hline Sorbitol & + & + & + & + & + & + & + \\
\hline \multicolumn{8}{|l|}{ Organic acids } \\
\hline Glucuronate & - & - & - & - & - & - & - \\
\hline DL-Lactate & - & - & - & + & + & - & - \\
\hline 2-Keto-gluconate & + & + & + & + & + & + & + \\
\hline Levulinate & - & - & - & - & - & - & - \\
\hline Gluconate & - & - & - & - & - & - & - \\
\hline \multicolumn{8}{|l|}{ Amino acids } \\
\hline$N$-Acetylglucosamine & + & + & + & + & + & + & + \\
\hline Glucosamine & + & + & + & + & + & + & + \\
\hline \multicolumn{8}{|l|}{ Nitrate $\nmid$} \\
\hline Potassium nitrate & - & - & - & - & - & - & - \\
\hline
\end{tabular}

*ID 32C assimilation profile codes: $A=7143140015$ (no definitive identification obtained using the APILAB database; includes NCPF 3108 ); $\mathrm{B}=7142140015$ (no definitive identification obtained using the APILAB database); $\mathrm{C}=7142100015$ (no definitive identification obtained using the $A P I L A B$ database); $132 \mathrm{~A}=7347140015$ (very good identification, $C$. albicans); $179 \mathrm{~B}=7347340015$ (excellent identification, C. albicans); ATCC11006 = 3142300015 (excellent identification, C. stellatoidea); ATCC $20408=3143300015$ (excellent identification, $C$. stellatoidea). All of the isolates tested grew in the presence of cyclohexamide and were unable to hydrolyse aesculin. Seventeen of the 20 nonoral C. albicans control clinical isolates yielded ID 32C assimilation profiles identical to that obtained with the C. albicans oral isolate 179B and the remaining three yielded profiles identical to that obtained with the $C$. albicans oral isolate $132 \mathrm{~A}$.

$\dagger$ Nitrate assimilation tests were performed as described by Buckley (1989). 
(a)
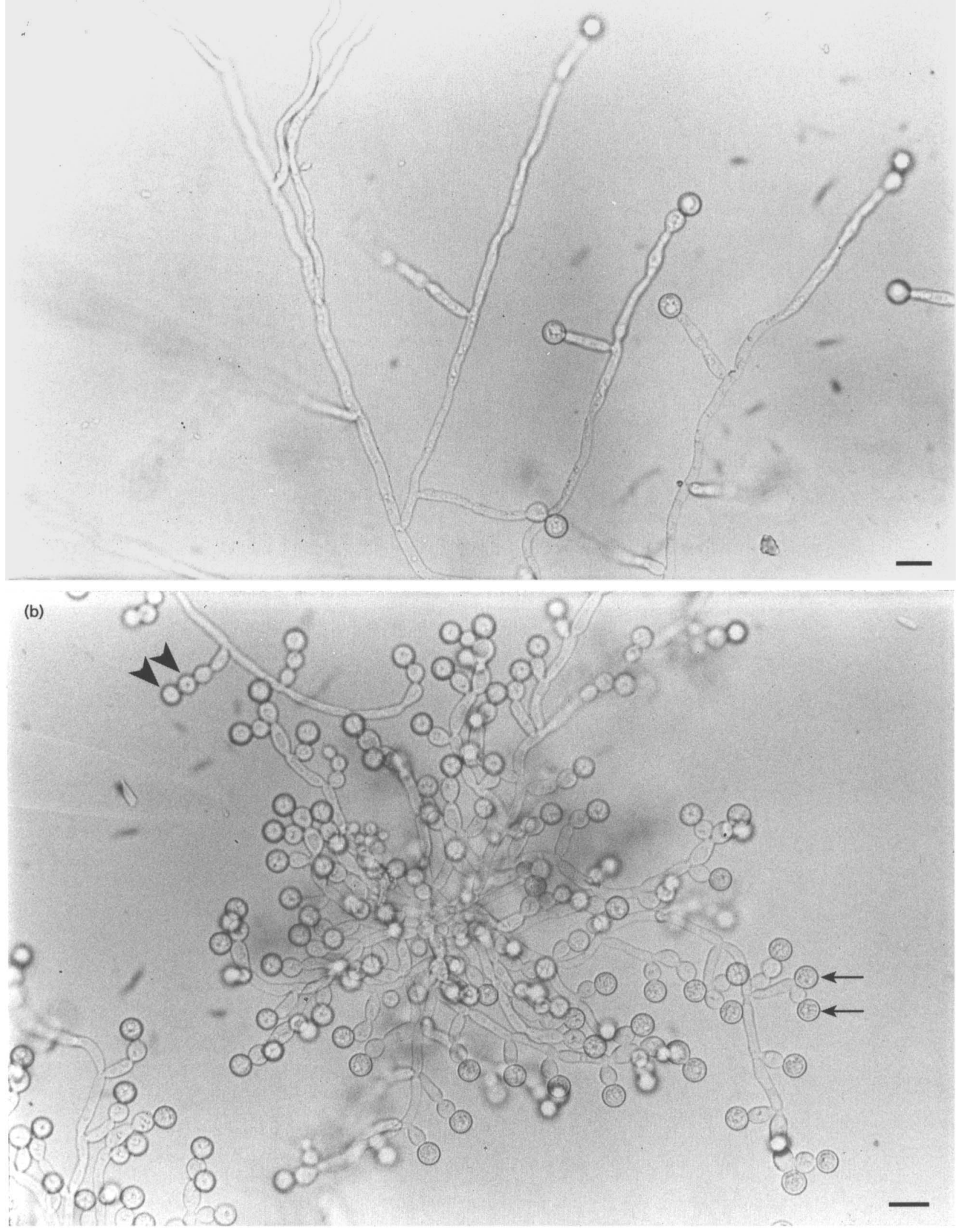

Fig. 1. For legend see page 1515. 

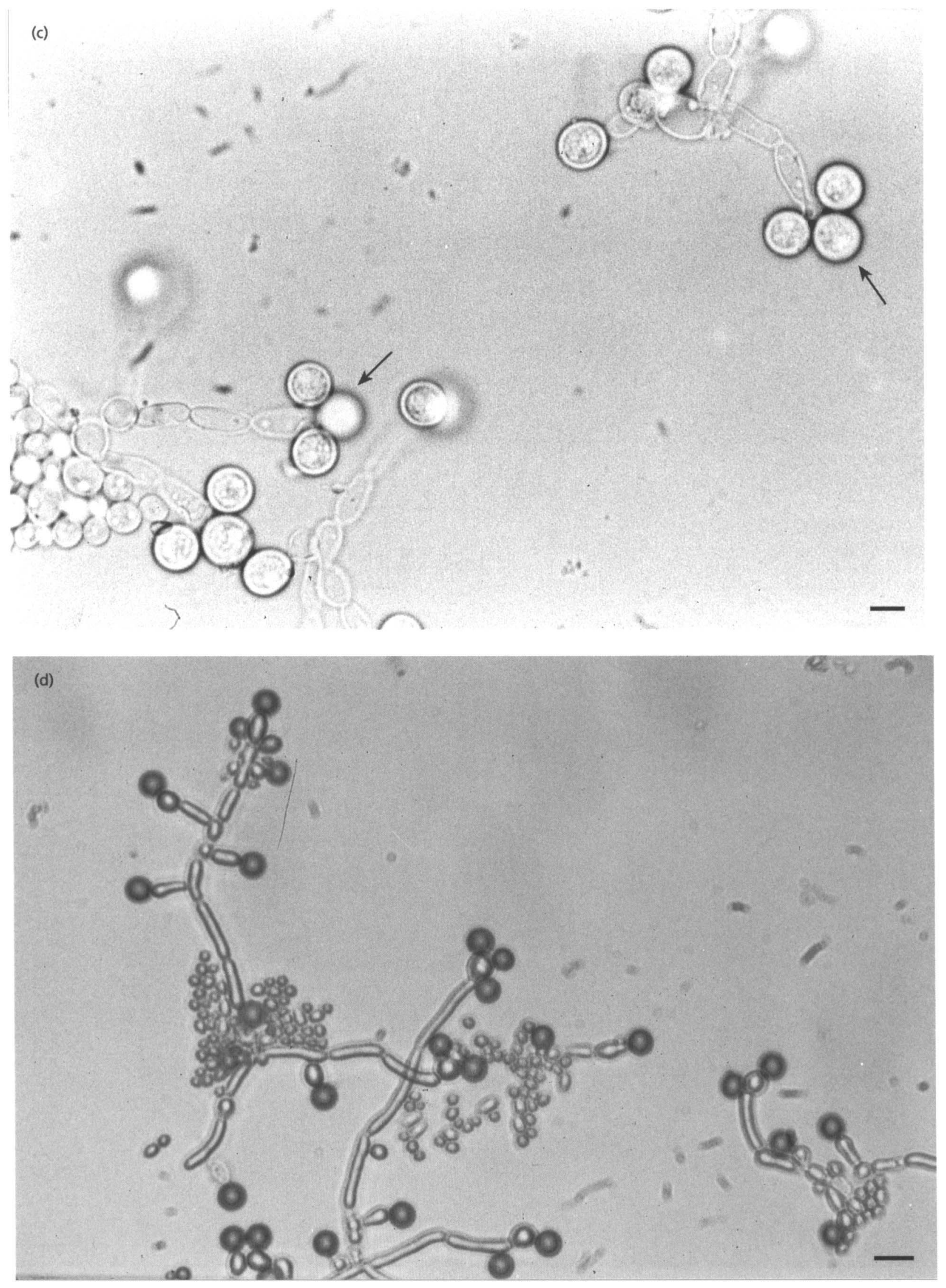

Fig. 1. For legend see facing page. 
(a)

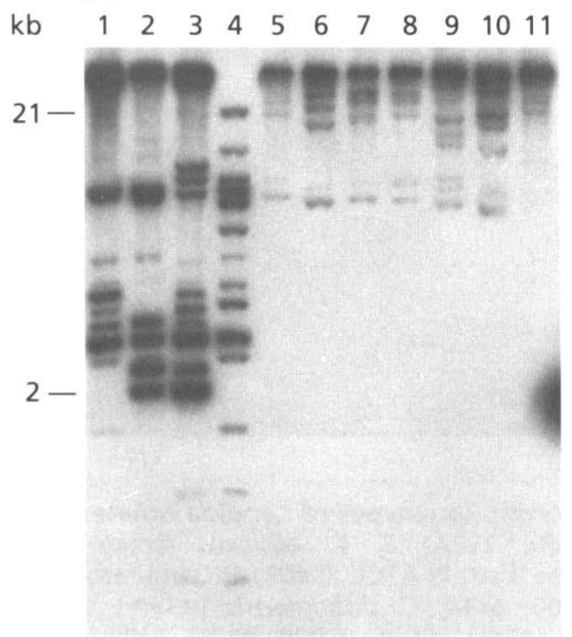

(b)

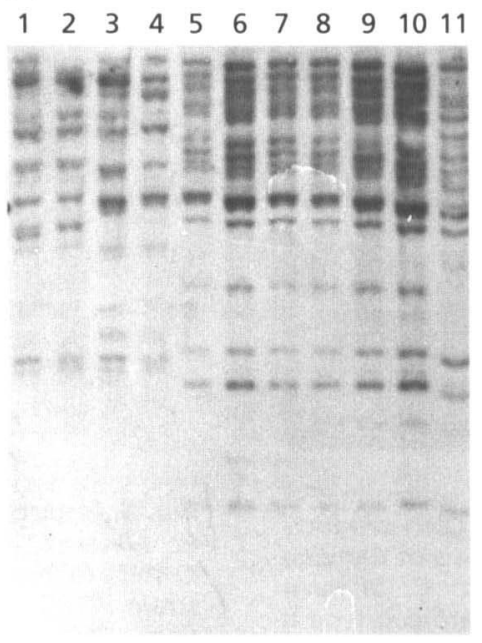

Fig. 2. Southern blot analysis of EcoRIdigested total genomic DNA from $C$. albicans and $C$. dubliniensis isolates probed with (a) 32P-labelled $C$. albicans-specific probe 27A and (b) 32P-labelled oligonucleotide (GGAT) $)_{4}$. The fingerprints shown correspond to $C$. albicans isolates $132 \mathrm{~A}$ (lane 1) and CM 3 (lane 2), C. stellatoidea type II strain ATCC 20408 (lane 3), C. stellatoidea type I strain ATCC 11006 (lane 4), C. dubliniensis isolates CD33 (lane 5), CD36 (lane 6), CD38 (lane 7), CM2 (lane 8), CM5 (lane 9) CM7 (lane 10) and NCPF 3108 (lane 11). Size reference markers are indicated in $\mathrm{kb}$ on the left of the figure. (a)

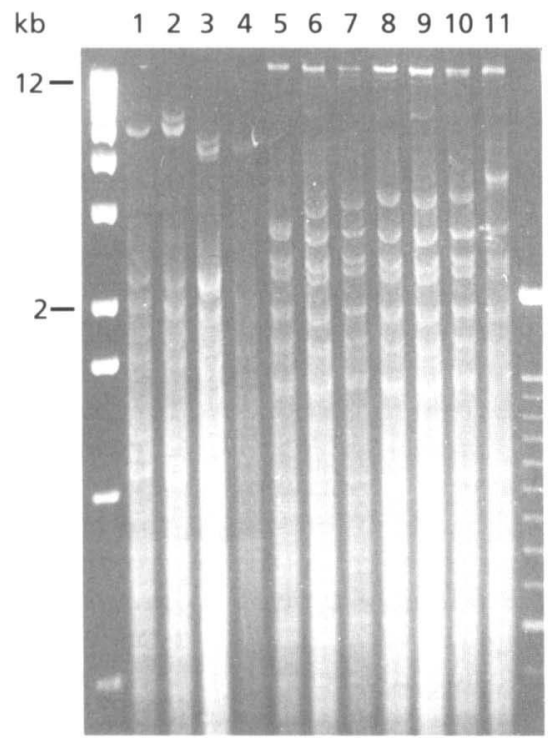

(b)

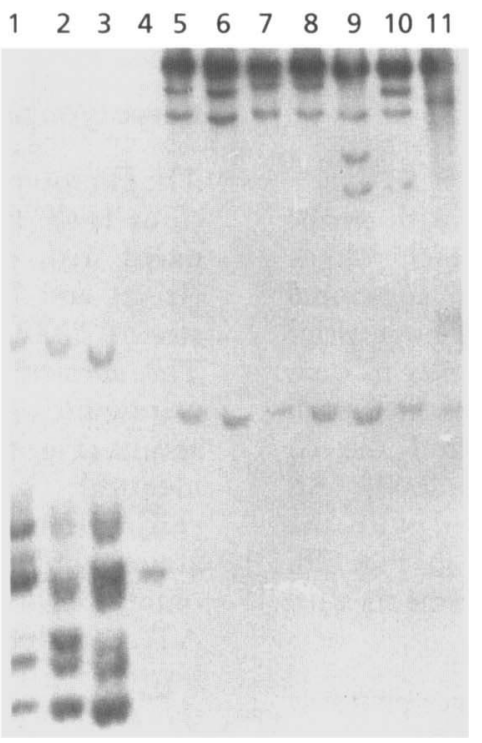

Fig. 3. (a) Agarose gel electrophoresis of total genomic DNA from Candida isolates digested with Hinfl. DNA was from organisms as follows: $C$. albicans isolates 132A (lane 1) and CM3 (lane 2), $C$. stellatoidea type II strain ATCC 20408 (lane 3), C. stellatoidea type I strain ATCC 11006 (lane 4), C. dubliniensis isolates CD33 (lane 5), CD36 (lane 6), CD38 (lane 7), CM2 (lane 8), CM5 (lane 9), CM7 (lane 10) and NCPF 3108 (lane 11). Size reference markers are indicated in $\mathrm{kb}$ on the left of the figure. The digested DNA shown in (a) was transferred onto a nylon membrane filter and probed with ${ }^{32}$ p-labelled $C$. albicans-specific probe $27 \mathrm{~A}$, generating the autoradiogram shown in (b).
(Fig. 3a). When hybridized with $27 \mathrm{~A}$, the probe bound almost exclusively to the high molecular mass Hinf fragment present in the atypical isolate genomic DNA digests (Fig. 3b).

All of the results described above strongly suggested that the genomic structure of the atypical isolates differed substantially from the reference $C$. albicans and $C$. stellatoidea strains examined. This suggestion was con- firmed following hybridization analysis of EcoRI-cleaved genomic DNA from seven representative atypical isolates (three Irish, three Australian and NCPF 3108), from the oral C. albicans strains 132A (Irish) and CM3 (Australian) and from the $C$. stellatoidea strains ATCC 11066 and ATCC 20408 with each of the five synthetic oligonucleotide probes $(\mathrm{GGAT})_{4},(\mathrm{GACA})_{4},(\mathrm{GATA})_{4},(\mathrm{GT})_{8}$ and (GTG $)_{5}$; (Table 2). In these experiments, the same nylon-membrane-bound DNA samples used in the

Fig. 1. Light micrographs showing chlamydospore production on RAT agar plates incubated at $25-27^{\circ} \mathrm{C}$ for $72 \mathrm{~h}$. (a) Chlamydospores and pseudohyphae produced by C. albicans strain 132A. (b) Production of abundant chlamydospores by the $C$. dubliniensis isolate CD33. Examples of contiguously arranged chlamydospores (arrowheads) and terminal pairs (arrows) are indicated. (c) Terminal triplet arrangements of chlamydospores (arrows) produced by $C$. dubliniensis isolate CD33. (d) Chlamydospores produced by C. dubliniensis isolate CD33 stained with lactophenol cotton blue. Bars: $10 \mu \mathrm{m}$ (a, b, d); $5 \mu \mathrm{m}$ (c). 


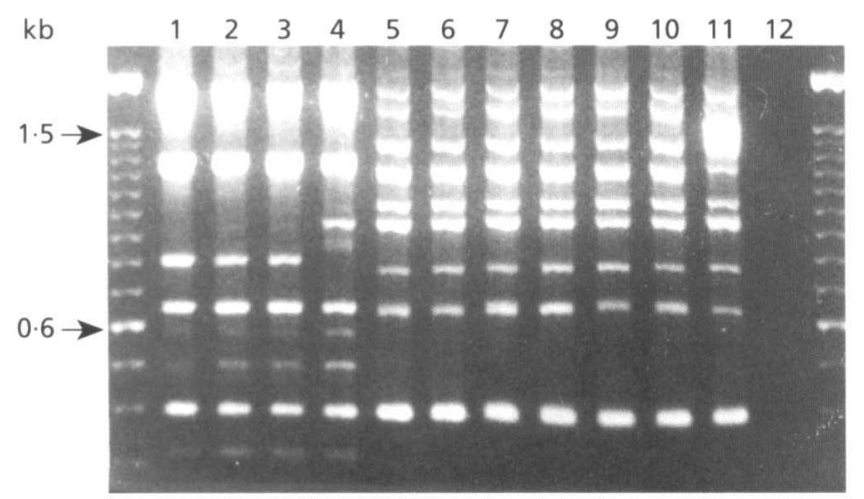

Fig. 4. Agarose gel electrophoresis of amplified DNA products generated using primer 6 (Table 2) in RAPD analysis of Candida isolates. The fingerprints shown correspond to $C$. albicans isolates 132A (lane 1) and CM3 (lane 2), C. stellatoidea type II strain ATCC 20408 (lane 3), C. stellatoidea type I strain ATCC 11006 (lane 4), C. dubliniensis isolates CD33 (lane 5), CD36 (lane 6), CD38 (lane 7), CM2 (lane 8), CM5 (lane 9), CM7 (lane 10) and NCPF 3108 (lane 11). A negative control in which no template DNA was used in the PCR reaction was also included (lane 12). Size reference markers are indicated in $\mathrm{kb}$ on the left of the figure.

hybridization experiments described above with probe $27 \mathrm{~A}$ were sequentially hybridized with each oligonucleotide probe, generating five distinct additional fingerprint profiles. In each case, the overall fingerprint profiles of the atypical isolates were very similar to each other, but quite distinct from the profiles obtained with the $C$. albicans isolates $132 \mathrm{~A}$ and $\mathrm{CM} 3$, and the $C$. stellatoidea strains ATCC 11006 and ATCC 20408. An example of the fingerprint profiles generated with the oligonucleotide probe $(\mathrm{GGAT})_{4}$ is shown in Fig. $2 \mathrm{~b}$. Identical results were obtained in repeat experiments with separate preparations of genomic DNA.

Further supporting data for the distinctive genomic organization of the atypical isolates was obtained by applying RAPD analysis to genomic DNA from the same organisms examined by hybridization analysis with the five oligonucleotide probes described above. An additional oligonucleotide primer (primer 6, Table 2) was used to generate RAPD profiles of each organism investigated. The overall RAPD profiles of the atypical isolates tested were very similar to each other (Fig. 4, lanes 5-11), but very distinct from the profiles obtained with the reference $C$. albicans and $C$. stellatoidea strains tested (Fig. 4, lanes 1-4). Identical results were obtained in repeat experiments with separate preparations of template genomic DNA from the same organisms. Further RAPD experiments employing four different oligonucleotide primers (primers 7-10, Table 2) and template DNA isolated from C. albicans strain $132 \mathrm{~A}$, C. stellatoidea strain ATCC 20408 (type II) and atypical isolates CD33 (Irish), CM2 (Australian) and NCPF 3108 , also resulted in the generation of very distinct RAPD patterns for the atypical isolates which were readily discernible from those generated from the reference strains (data not shown).

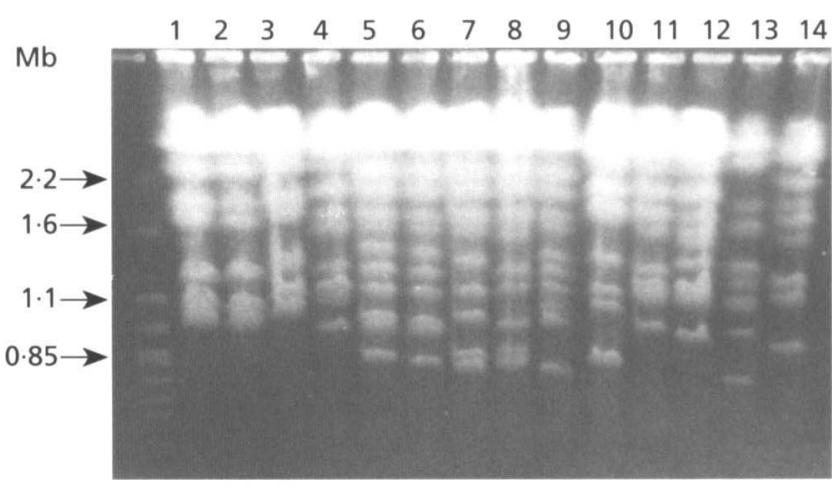

Fig. 5. Electrophoretic karyotypes of Candida isolates. Lanes: 1, C. albicans isolate 132A; 2, C. albicans isolate CM3; 3 , C. stellatoidea type II strain ATCC 20408; 4, C. stellatoidea type I strain ATCC 11006; 5-14, C. dubliniensis isolates CM1, CM2, CM4, CM5, CM6, CD33, CD36, CD38, NCPF 3108 and CD41, respectively. Chromosomes from Saccharomyces cerevisiae, used as molecular mass standards (Bio-Rad), are on the left of the figure and the molecular masses indicated are in $\mathrm{Mb}$.

\section{Karyotype analysis}

The karyotype profiles of a selection of 10 atypical isolates (four Irish, five Australian and NCPF 3108) were compared with those of the oral C. albicans isolates 132A (Irish) and CM3 (Australian), and both C. stellatoidea strains ATCC 11006 (type I) and ATCC 20408 (type II). The atypical isolates yielded karyotype profiles which were quite distinct from those obtained for the reference strains (Fig. 5). C. albicans 132A and CM3 yielded almost identical karyotypes containing seven distinct chromosome-sized bands. Interestingly, this pattern was almost indistinguishable from the karyotype pattern obtained with the reference type II C. stellatoidea strain ATCC 20408 (Fig. 5, lane 3). This type of pattern, however, is significantly different from that obtained with the reference type I C. stellatoidea strain ATCC 11006, which contained nine chromosome-sized bands (Fig. 5, lane 4). Similarly, the karyotype patterns obtained with the atypical isolates were quite distinct from the $C$. albicans patterns, with most of the profiles containing 9 or 10 individual chromosome-sized bands (Fig. 5, lanes 5-14). One apparent characteristic feature of the atypical isolates karyotype profiles was the presence of one or more chromosome-sized bands of $<1 \mathrm{Mb}$, a feature also displayed by the reference type I $C$. stellatoidea strain ATCC 11006.

\section{Analysis of ribosomal RNA gene nucleotide sequences}

Approximately $600 \mathrm{bp}$ of DNA from the V3 variable region of the large ribosomal subunit genes were amplified by PCR from genomic DNA of nine representative atypical isolates (five Irish, three Australian and NCPF 3108; see Table 1) from the C. albicans strains $132 \mathrm{~A}$ and 179B, and from the C. stellatoidea strains ATCC 11006 


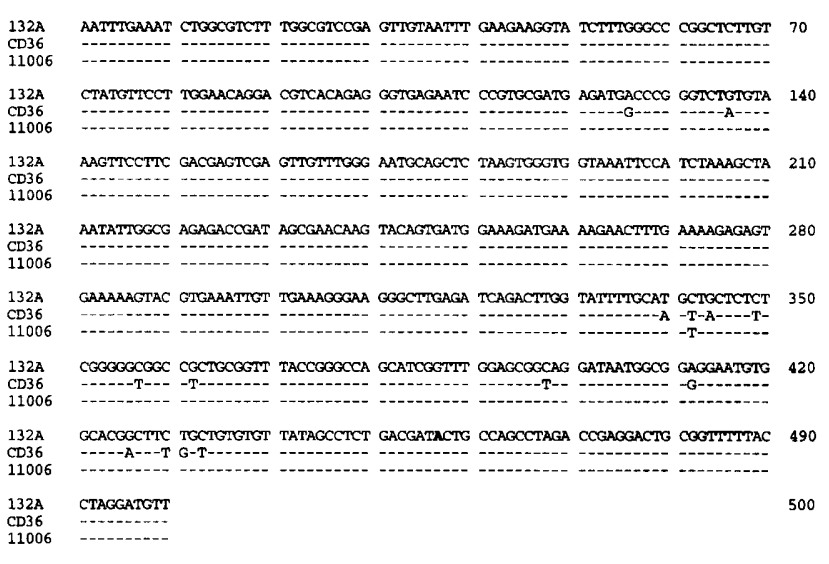

Fig. 6. Comparison of partial nucleotide sequences of the V3 region of the large ribosomal subunit genes of $C$. albicans 132A, C. dubliniensis CD36 and C. stellatoidea type I strain ATCC 11006. Sequence matches are indicated by dashes. The base adenine shown in bold at position 457 was replaced by a guanine in the corresponding sequence of $C$. albicans strain wo-1.

(type I) and ATCC 20408 (type II). In each case the nucleotide sequence of the amplified DNA was determined on both strands and the data compared using the same 500 bp of completely unambiguous sequence. These sequences have been submitted to the EMBL nucleotide sequence database (Table 1). The sequences obtained from the oral $C$. albicans strains $132 \mathrm{~A}$ and $179 \mathrm{~B}$ were identical, but differed at a single base, at position 457 (Fig. 6 ), from the corresponding sequences of $C$. albicans strain WO-1 (isolated from blood) and two $C$. albicans vaginal isolates, the sequences of which were obtained from the GenBank and EMBL nucleotide sequence databases, respectively (Srikantha et al., 1994; Mercure et al., 1993; Table 1). The sequences of the corresponding regions of the C. stellatoidea strains ATCC 11006 (type I) and ATCC 20408 (type II) were also found to be identical to each other, but differed from the sequence of $C$. albicans strain $132 \mathrm{~A}$ by only a single base at position 342 and from that of strain WO-1 at two positions (i.e. bases 342 and 457, see Fig. 6). Analysis of the corresponding sequences from the nine atypical isolates tested (Table 1) revealed that they were all identical to each other, but that they differed from the $C$. albicans $132 \mathrm{~A}$ sequence at the same 14 positions in each case, from the $C$. albicans WO-1 sequence at an additional position (i.e. a $15 \mathrm{bp}$ difference in total) and from the $C$. stellatoidea strains ATCC 11066 and ATCC 20408 sequences at the same 13 positions. Alignments of a representative sequence from an atypical isolate, and one sequence from each of the $C$. albicans and $C$. stellatoidea reference strains tested are shown in Fig. 6.

For comparison, since there was no corresponding sequence data in the databases for species of Candida other than C. albicans, DNA fragments were also amplified from the corresponding region of the ribosomal genes from one isolate each of five other Candida species, including $C$. tropicalis, C. glabrata, C. krusei, C. parapsilosis and C. kefyr, and from that of a single isolate of Aspergillus fumigatus. These sequences have been submitted to the GenBank nucleotide sequence database (Table 1). In each case the amplified products were sequenced on both strands and aligned with the corresponding sequences obtained from a representative atypical isolate and from reference strains of $C$. albicans and $C$. stellatoidea. The sequence data obtained from the five 'non-albicans' Candida species and the strain of Aspergillus fumigatus differed considerably from the $C$. albicans sequence data. An evolutionary distance matrix (Table 4) based on these sequences was compiled from the 10 aligned sequences, correcting for multiple base changes according to Jukes \& Cantor (1969). Using this data, an evolutionary tree was generated employing the neighbour-joining method of Saitou \&

Table 4. Genetic distance matrix based on comparison of sequences of the V3 region of the large ribosomal subunit

Values correspond to percentages of difference corrected for multiple base changes by the method of Jukes \& Cantor (1969).

\begin{tabular}{|c|c|c|c|c|c|c|c|c|c|c|}
\hline & C. du. & $\begin{array}{c}\text { C. al. } \\
\text { (132A) }\end{array}$ & $\begin{array}{c}\text { C. al. } \\
\text { (WO-1) }\end{array}$ & C.st. & C. tr. & C.pa. & C. ke. & C. $g l$. & A. fu. & C. kr. \\
\hline C. dubliniensis (CD36)* & - & & & & & & & & & \\
\hline C. albicans $(132 \mathrm{~A})$ & $2 \cdot 25$ & - & & & & & & & & \\
\hline C. albicans (WO-1) $\dagger$ & $2 \cdot 48$ & 0.02 & - & & & & & & & \\
\hline C. stellatoidea (20408)‡ & $2 \cdot 25$ & $0 \cdot 00$ & 0.02 & - & & & & & & \\
\hline C. tropicalis (3111) & $6 \cdot 71$ & $7 \cdot 70$ & $7 \cdot 95$ & $7 \cdot 70$ & - & & & & & \\
\hline C. parapsilosis (44) & $7 \cdot 96$ & 8.97 & $9 \cdot 23$ & 8.97 & $5 \cdot 26$ & - & & & & \\
\hline C. kefyr (3234) & $15 \cdot 76$ & $16 \cdot 32$ & $16 \cdot 60$ & $16 \cdot 32$ & $17 \cdot 09$ & $15 \cdot 23$ & - & & & \\
\hline C. glabrata (11088A) & $20 \cdot 29$ & $20 \cdot 27$ & $20 \cdot 57$ & $20 \cdot 27$ & $20 \cdot 78$ & $21 \cdot 52$ & $12 \cdot 58$ & - & & \\
\hline A. fumigatus (2109) & $27 \cdot 53$ & 26.56 & $26 \cdot 23$ & $26 \cdot 56$ & $29 \cdot 93$ & $29 \cdot 36$ & $30 \cdot 46$ & $29 \cdot 95$ & - & \\
\hline C. krusei (105-1) & $29 \cdot 60$ & $29 \cdot 93$ & $29 \cdot 60$ & $29 \cdot 93$ & $32 \cdot 62$ & $32 \cdot 67$ & $33 \cdot 84$ & $35 \cdot 92$ & $37 \cdot 53$ & - \\
\hline
\end{tabular}

*All eight isolates tested, in addition to NCPF 3108, yielded identical sequences.

† The sequence for $C$. albicans strain WO-1 was obtained from the GenBank database (accession no. L28817).

$\ddagger$ The type I and type II C. stellatoidea strains (ATCC 11006 and 20408, respectively) yielded identical sequences. 


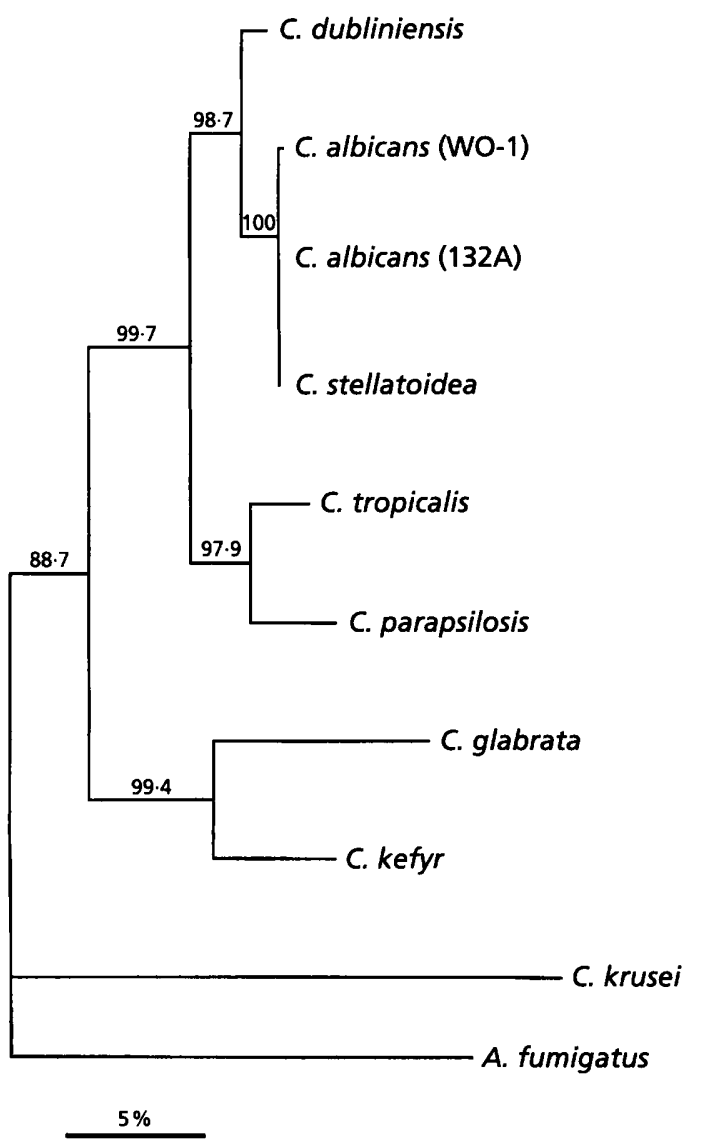

Fig. 7. An unrooted phylogenetic neighbour-joining tree generated from the alignment of a $500 \mathrm{bp}$ section of the V3 region of the large ribosomal genes from $C$. dubliniensis CD36 and species listed in Table 1 . The scale bar represents a $5 \%$ difference in nucleotide sequence. Numbers at each node were generated by bootstrap analysis and represent the percentage of times the arrangement occurred in 1000 randomly generated trees.

Nei (1987) (Fig. 7). When a bootstrap analysis of the 10 aligned sequences was performed, the cluster of $C$. dubliniensis, $C$. albicans WO-1, C. albicans $132 \mathrm{~A}$ and $C$. stellatoidea occurred in 987 of 1000 trees. Thus, in $98.7 \%$ of the trees generated $C$. dubliniensis was grouped separately from $C$. albicans and $C$. stellatoidea.

These findings provided strong evidence that $C$. dubliniensis constitutes a discrete taxon within the genus Candida.

\section{DISCUSSION}

We have identified a novel yeast which produces abundant chlamydospores from the oral cavities of HIV-infected individuals presenting with oral candidosis and from a small number of HIV-negative subjects and have described its phenotypic and genotypic properties. It remains to be elucidated whether these yeasts occur in other anatomical sites and other subject populations. Having considered the characteristics of these isolates in relation to the genus Candida, we consider them to constitute a previously undescribed species of Candida, for which we propose the name Candida dubliniensis. Two phenotypic characteristics, including the ability to produce chlamydospores and germ tubes, were those specifically associated with only two Candida species, $C$. albicans and $C$. stellatoidea (Odds, 1988c). The inability to grow at $42{ }^{\circ} \mathrm{C}$ is also a characteristic feature of type $\mathrm{I} C$. stellatoidea but not of $C$. albicans (Kamiyama et al., 1989) or type II $C$. stellatoidea (sucrose-negative variants of $C$. albicans, Kwon-Chung et al., 1988) both of which grow at this temperature. $C$. dubliniensis could be distinguished from type I $C$. stellatoidea by its ability to assimilate sucrose, although it should be noted that a recent study reported that prolonged exposure to sucrose can induce type I $C$. stellatoidea to form sucrose-positive variants (Wickes et al., 1991). C. dubliniensis, which belongs to serotype A, could also be distinguished from type I $C$. stellatoidea on the basis of serotype, the latter of which belong to serotype B (Kwon-Chung et al., 1989). In addition, $C$. dubliniensis could also be readily distinguished from $C$. albicans and $C$. stellatoidea by its consistent production of abundant chlamydospores on RAT and cornmeal agar. Furthermore, chlamydospores were often observed in triplets or in contiguous pairs attached to a single suspensor cell, a feature that was rarely observed in over 400 oral isolates of $C$. albicans from separate Irish HIV-infected and control subjects or in other reference strains and control isolates of $C$. albicans or C. stellatoidea tested. As far as we are aware, production of contiguous chlamydospores has only been described once before, in a study of oral isolates of C. albicans (Akisada et al., 1983). To ensure that the reference $C$. albicans isolates used in this study were representative of the species from a taxonomic viewpoint, both oral and non-oral isolates were examined and the data obtained with both groups were found to be entirely consistent.

Genotypic studies clearly reinforced the suggestion obtained from phenotypic tests of the unique nature of $C$. dubliniensis relative to other species of the genus Candida, with particular reference to $C$. albicans and C. stellatoidea. C. dubliniensis genomic DNA hybridized poorly with the cloned C. albicans-specific, dispersed mid-repeat sequence probe $27 \mathrm{~A}$, relative to genomic DNA from C. albicans and C. stellatoidea. Since $27 \mathrm{~A}$ and similar probes hybridize well with repetitive DNA sequences dispersed throughout the genome of C. albicans (including oral and non-oral isolates) and C. stellatoidea (Scherer \& Stevens, 1988; KwonChung et al., 1989; this study), this finding suggested that the genomic organization of $C$. dubliniensis is significantly different. Further evidence establishing the distinctive genomic organization of $C$. dubliniensis was obtained following DNA fingerprint analysis using a range of five different oligonucleotide probes homologous to eukaryotic microsatellite DNA sequences, and by RAPD analysis with an additional five oligonucleotides. Furthermore, this distinctive genomic organization was paralleled by the patterns of chromosome-sized DNA bands exhibited by $C$. dubliniensis following PFGE. A feature shared with type I C. stellatoidea, but not with the 
majority of C. albicans isolates (Kwon-Chung et al., 1988), was the presence of chromosome-sized molecules of $<1 \mathrm{Mb}$.

Previous studies involving sequence analysis of the V3 variable regions of large ribosomal RNA gene sequences have provided very useful information concerning the phylogenetic relationships between a variety of marine yeasts (Fell et al., 1992). Analysis of a 500 bp sequence from the corresponding region of the large ribosomal subunit rRNA genes of $C$. dubliniensis and seven other Candida species tested, including $C$. albicans and $C$. stellatoidea, revealed significant differences (Table 4, Figs 6 and 7). Analysis of sequence data obtained from nine epidemiologically unrelated $C$. dubliniensis isolates (five Irish, three Australian and NCPF 3108; Table 1) demonstrated that $C$. dubliniensis formed a homogeneous cluster (100\% similarity) representing a unique taxon within the genus Candida, and clearly separated from the other Candida species tested (Table 4, Figs 6 and 7). The closest species linked to the cluster were C. stellatoidea $(2.25 \%$ sequence divergence) and $C$. albicans $(2 \cdot 25-2 \cdot 48 \%$ sequence divergence) (Table 4, Figs 6 and 7). The almost identical sequences obtained with the $C$. albicans and $C$. stellatoidea strains examined in the present study reinforces the concept that both of these groups of organisms are probably not separate species. However, the significant genetic divergence found between $C$. albicans and $C$. dubliniensis indicates strongly that $C$. dubliniensis should be considered a separate species.

\section{Description of Candida dubliniensis sp. nov.}

Candida dubliniensis [dubliniensis; after Dublin, capital city of the Republic of Ireland].

Dimorphic yeast consisting of ovoid or spherical blastospores $(3-7 \mu \mathrm{m} \times 3-14 \mu \mathrm{m})$. Grows as round convex cream-coloured colonies on Sabouraud dextrose agar (Oxoid) and cream-white-coloured colonies on Potato Dextrose agar (Oxoid). On RAT agar (bioMérieux) or cornmeal-Tween 80 agar at $25-27^{\circ} \mathrm{C}$ for $48-72 \mathrm{~h}$, produces pseudohyphae (and a few true hyphae) with short unilateral, bilateral or multilateral branches at the septa and produces abundant refractile, thick-walled chlamydospores. Chlamydospores are often produced in triplets or in contiguous pairs attached terminally by single suspensor cells to extensively branched pseudohyphae. Produces germ tubes in fresh, pooled normal human serum following $2 \mathrm{~h}$ incubation at $37^{\circ} \mathrm{C}$ in a waterbath. Grows well at $30^{\circ} \mathrm{C}$ and at $37^{\circ} \mathrm{C}$ but not at $42{ }^{\circ} \mathrm{C}$. Biochemically, strains assimilate galactose, glucose, maltose, sucrose, mannitol, sorbitol, 2-keto-gluconate and glucosamine, and do not assimilate arabinose, xylose, ribose, sorbose, rhamnose, $\alpha$-methyl-D-glucoside, cellobiose, lactose, melibiose, melezitose, rafinose, glycerol, erythritol, inositol, glucuronate, DL-lactate, levulinate, gluconate or potassium nitrate. Strains show variable assimilation of palatinose and trehalose, grow in the presence of cycloheximide and do not hydrolyse aesculin. Belongs to $C$. albicans serotype A (i.e. agglutinated with polyclonal antisera raised against Candida antigenic factor No. 6).

C. dubliniensis has a unique organization of genomic DNA relative to other Candida species as determined by DNA fingerprint analysis of genomic DNA with the $C$. albicansspecific mid-repeat sequence probe $27 \mathrm{~A}$, the oligonucleotide probes $(\mathrm{GGAT})_{4},(\mathrm{GACA})_{4},(\mathrm{GATA})_{4},(\mathrm{GT})_{8}$ and $(\mathrm{GTG})_{5}$, and by karyotype analysis and nucleotide sequence analysis of the $\mathrm{V} 3$ variable region of the large ribosomal subunit gene DNA.

The type strain is CD36 which has been lodged with the British National Collection of Pathogenic Fungi (Mycology Reference Laboratory, Bristol Public Health Laboratory, Kingsdown, Bristol BS2 8EL, UK) under the accession number NCPF 3949 (Table 1).

\section{Latin description of Candida dubliniensis sp. nov.}

Candida dubliniensis (de Dublinio, rei publicae Hiberniae capite).

Fermentum biforme ex ovoideis vel sphaeralibus blastosporis (3.0-7.0 $\mu \mathrm{m} \times$ 3-14 $\mu \mathrm{m})$ formatum. Coloniae flavalbidae, rotundatae et convexae nascuntur in agaro dextroso Sabouraudo (Oxoid), coloniae albicerae in agaro dextroso solani tuberosi (Oxoid). Culturum in agaro Tween (bioMérieux) oryzae vel Tween 80 frumenti (post dies 2-3, 25-27 ${ }^{\circ} \mathrm{C}$ ), fert pseudohyphas et aliquot veras byphas, quae ad septa in breves, simplices vel ancipites vel multiplices ramos dividuntur; nimis effert chlamydosporas refractiles et callosas. Haec chlamydosporae saepe trinae producuntur vel binae et adiunctae extremo cellulis singulis ad pseudobyphas multirames. In sano et recenti sero bumano, post duas horas $\left(37^{\circ} \mathrm{C}\right)$, germina tubulata formantur. Sub 30 et $37^{\circ} \mathrm{C}$ bene crescit, sed sub $42^{\circ} \mathrm{C}$ non crescit. Assimilat galactosum, glucosum, maltosum, sucrosum, mannitolum, sorbitolum, 2-keto-gluconatum, glucosaminum. Non assimilat arabinosum, xylosum, ribosum, sorbosum, rbamnosum, $\alpha$-metbylD-glucosidum, cellobiosum, lactosum, melibiosum, melezitosum, rafinosum, glycerolum, erytbritolum, inositolum, glucuronatum, DL-lactatum, levulinatum, gluconatum, vel nitratem kalicum. Palatinosum et trehalosum assimilantur inconstanter. Cyclobeximido praesente crescit, sed aesculinum non bydrolysit. Attinet ad Candidae albicantis serotypum $A$ (id est polyclonalibus antiseris agglutinatum, quae provocata sunt a factore Candidam inbibente 6).

Candidae dubliniensis genomi unice ordinantur. Typus e lingua bominis HIV infecti isolatus CD36 (NCPF 3949, Tabula 1).

\section{Description of the type strain}

Strain CD36 has all the above-mentioned characteristics, including the ability to assimilate palatinose and trehalose. It was isolated from the mid-dorsum of the tongue of an Irish HIV-infected subject presenting with erythematous oral candidosis during 1988.

\section{ACKNOWLEDGEMENTS}

This work was supported by the Irish Health Research Board Opportunistic Infection in AIDS Programme grant and the Westminster Joint Research Trust. T. W. was funded by a grant from the RIVM, The Netherlands. We thank Dr Stephen Flint 
(Dublin Dental Hospital) and Dr Michael McCullough (Melbourne) for supplying isolates, Dr Martin Henman (University of Dublin) for critically reviewing the manuscript and Dr Judith Mossman (University of Dublin) for preparing the Latin translation of the description of Candida dubliniensis sp. nov. We would also like to gratefully acknowledge the constant encouragement and support of Professor D. Shanley (Dublin Dental Hospital).

\section{REFERENCES}

Akisada, T., Harada, K., Niimi, M. \& Kamaguchi, A. (1983). Production of contiguously arranged chlamydospores in Candida albicans. J Gen Microbiol 129, 2327-2330.

Akopyanz, N., Bukanov, N. O., Westblom, T. U., Kresovich, S. \& Berg, D. E. (1992). DNA diversity among clinical isolates of Helicobacter pylori detected by PCR-based RAPD fingerprinting. Nucleic Acids Res 20, 5137-5142.

Allen, C. M. \& Beck, F. M. (1983). Strain-related differences in pathogenicity of Candida albicans for oral mucosa. J Infect Dis 147, 1036-1040.

Barnett, J. A., Payne, R. W. \& Yarrow, D. Y. (1990). Descriptions of the species arranged alphabetically. In Yeasts: Characteristics and Identification, 2nd edn, pp. 79-695. Cambridge: Cambridge University Press.

Buckley, H. R. (1989). Identification of yeasts. In Medical Mycology: A Practical Approach, pp. 97-109. Edited by E. G. V. Evans \& M. D. Richardson. Oxford: IRL Press.

Check, W. A. (1994). Molecular techniques shed light on fungal genetics. ASM News 60, 593-596.

Coleman, D. C., Arbuthnott, J. P., Pomeroy, H. M. \& Birkbeck, T. H. (1986). Cloning and expression in Eschericbia coli and Stapbylococcus aureus of the beta-lysin determinant from Staphylococcus aureus: evidence that bacteriophage conversion of beta-lysin activity is caused by insertional inactivation of the beta-lysin determinant. Microb Pathogen 1, 549-564.

Coleman, D. C., Bennett, D. E., Sullivan, D. J., Gallagher, P. J., Henman, M. C., Shanley, D. B. \& Russell, R. J. (1993). Oral Candida in HIV infection and AIDS: new perspectives/new approaches. Crit Rev Microbiol 19, 61-82.

Durkacz, B., Beach, D., Hayles, J. \& Nurse, P. (1985). The fission yeast cell cycle control gene $c d c 2$ : structure of the $c d c 2$ region. Mol \& Gen Genet 201, 543-545.

Edman, J. C., Kovacs, A. J., Masur, H., Santi, D. V., Elwood, H. J. \& Sogin, M. L. (1988). Ribosomal RNA sequence shows Pneumocystis carinii to be a member of the fungi. Nature 334, 519-522.

Fell, J. W. (1993). Rapid identification of yeast species using three primers in a polymerase chain reaction. Mol Mar Biol Biotechnol 3, 174-180.

Fell, J. W., Statzell-Tallman, A., Lutz, M. R. \& Kurtzman, C. P. (1992). Partial rRNA sequences in marine yeasts: a model for identification of marine eukaryotes. Mol Mar Biol Biotechnol 1, 175-186.

Felsenstein, J. (1985). Confidence limits on phylogenies: an approach using the bootstrap. Evolution 39, 783-791.

Gallagher, P. J., Bennett, D. E., Henman, M. C., Russell, R. J., Flint, S. R., Shanley, D. B. \& Coleman, D. C. (1992). Reduced azole susceptibility of oral isolates of $C$. albicans from HIV-positive patients and a derivative exhibiting colony morphology variation. J Gen Microbiol 138, 1901-1911.
Ghannoum, M. A., Swairjo, I. \& Soll, D. R. (1990). Variation in lipid and sterol contents in Candida albicans white and opaque phenotypes. J Med Vet Mycol 28, 103-115.

Jukes, T. H. \& Cantor, C. R. (1969). Evolution of protein molecules. In Mammalian Protein Metabolism, vol. 3, pp. 21-132. Edited by H. N. Munro. New York: Academic Press.

Kamiyama, A, Niimi, M., Tokunaga, M. \& Nakayama, H. (1989). Adansonian study of Candida albicans: intraspecific homogeneity excepting C. stellatoidea strains. J Med Vet Mycol 27, 229-241.

Kwon-Chung, K. J., Wickes, B. L. \& Merz, W. G. (1988). Association of electrophoretic karyotype of Candida stellatoidea with virulence for mice. Infect Immun 56, 1814-1819.

Kwon-Chung, K. J., Riggsby, W. S., Uphoff, R. A., Hicks, J. B., Whelan, W. L., Reiss, E., Magee, B. B. \& Wickes, B. L. (1989). Genetic differences between type I and type II Candida stellatoidea. Infect Immun 57, 527-532.

Larone D. H. (1993). Staining methods. In Medically Important Fungi: A Guide to Identification, pp. 186-192. Edited by D. H. Larone. Washington, DC: ASM.

McCullough, M., Ross, B. \& Reade, P. (1995). Characterization of genetically distinct subgroup of Candida albicans strains isolated from oral cavities of patients infected with human immunodeficiency virus. J Clin Microbiol 33, 696-700.

Mahrous, M., Lott, T. J., Meyer, S. A., Sawant, A. D. \& Ahearn, D. G. (1990). Electrophoretic karyotyping of typical and atypical Candida albicans. J Clin Microbiol 28, 876-881.

Marichal, P., Gorrens, J., Van Cutsem, J. \& Van Den Bossche, H. (1986). Culture media for the study of the effects of azole derivatives on germ tube formation and hyphal growth of $C$. albicans. Mykosen 29, 76-81.

Martinez, J. P., Gill, L., Casanova, M., Ribot-Lopez, J., De Lomas, J. G. \& Sentandreu, R. (1990). Wall mannoproteins in cells from colonial phenotypic variants of Candida albicans. J Gen Microbiol 136, 2421-2432.

Mercure, S., Rougeau, N., Montplaisir, S. \& Lemay, G. (1993). The nucleotide sequence of the $25 \mathrm{~S}$ rRNA-encoding gene from Candida albicans. Nucleic Acids Res 21, 1490.

Odds, F. C. (1988a). Pathogenesis of candidosis. In Candida and Candidosis, pp. 252-278. Edited by F. C. Odds. London: Baillière Tindall.

Odds, F. C. (1988b). Biological aspects of pathogenic Candida species. In Candida and Candidosis, pp. 7-15. Edited by F. C. Odds. London: Baillière Tindall.

Odds, F. C. (1988c). Morphogenesis in Candida, with special reference to Candida albicans. In Candida and Candidosis, pp. 42-59. Edited by F. C. Odds. London: Baillière Tindall.

Pearce, M. A. \& Howell, S. A. (1991). Restriction fragment length polymorphism analysis of azole-resistant and azole-susceptible Candida albicans strains. J Clin Microbiol 29, 1364-1367.

Saitou, N. \& Nei, M. (1987). The neighbour-joining method: a new method for reconstructing phylogenetic trees. Mol Biol Evol 4, 406-425.

Sambrook, J., Fritsch, E. F. \& Maniatis, T. (1989). Molecular Cloning: A Laboratory Manual. Cold Spring Harbor, NY: Cold Spring Harbor Laboratory.

Scherer, S. \& Stevens, D. A. (1988). A Candida albicans dispersed, repeated gene family and its epidemiologic applications. Proc Natl Acad Sci US A 85, 1452-1456.

Schmid, J., Odds, F. C., Wiselka, M. J., Nicholson, K. G. \& Soll, D. R. (1992). Genetic similarity and maintenance of Candida albicans 
strains from a group of AIDS patients, demonstrated by DNA fingerprinting. J Clin Microbiol 30, 935--941.

Slutsky, B., Staebell, M., Anderson, J., Risen, L., Pfaller, M. \& Soll, D. R. (1987). 'White-opaque transition': a second high-frequency switching system in Candida albicans. J Bacteriol 169, 189-197.

Southern, E. M. (1975). Detection of specific sequences among DNA fragments separated by gel electrophoresis. J Mol Biol 98, 503-517.

Srikantha, T., Gutell, R. R., Morrow, B. \& Soll, D. R. (1994). Partial nucleotide sequence of a single ribosomal RNA coding region and secondary structure of the large subunit $25 \mathrm{~S}$ rRNA of Candida albicans. Curr Genet 26, 321-328.

Sullivan, D., Bennett, D., Henman, M., Harwood, P., Flint, S., Mulcahy, F., Shanley, D. \& Coleman, D. (1993). Oligonucleotide fingerprinting of isolates of Candida species other than C. albicans and of atypical Candida species from human immunodeficiency virus-positive and AIDS patients. J Clin Microbiol 31, 2124-2133.

Thompson, J. D., Higgins, D. G. \& Gibson, T. J. (1994). CLustAL w : improving the sensitivity of progressive multiple sequence align- ment through sequence weighting, position-specific gap penalties and weight matrix choice. Nucleic Acids Res 22, 4673-4680.

Vazquez, J. A., Beckley, A., Sobel, J. D. \& Zervo, M. J. (1991). Comparison of restriction enzyme analysis and pulsed-field gradient gel electrophoresis as typing systems for Candida albicans. $J$ Clin Microbiol 29, 962-967.

Wakefield, A. E., Peters, S. E., Banerji, S., Bridge, P. D., Hall, G. S., Hawksworth, D. L., Guiver, L. A., Allen, A. G. \& Hopkin, J. M. (1992). Pneumocystis carinii shows DNA homology with the ustomycetous red yeast fungi. Mol Microbiol 6, 1903-1911.

Wickes, B. L., Golin, J. E. \& Kwon-Chung, K. J. (1991). Chromosomal rearrangement in Candida stellatoidea results in a positive effect on phenotype. Infect Immun 59, 1762-1771.

Williamson, M. I., Samaranayake, L. P. \& MacFarlane, T. W. (1986). Biotypes of oral Candida albicans and Candida tropicalis isolates. J Med Vet Mycol 24, 81-84.

Received 6 March 1995; revised 26 April 1995; accepted 3 May 1995. 